\title{
Pozór w edukacji osób z głęboką intelektualną i wieloraką niepełnosprawnością
}

\section{KEYWORDS}

the pretence, phenomenon of the "empty minutes", the person with profound intellectual and multiple disabilities, the remedial activities

\begin{abstract}
Danuta Kopeć, Pozór w edukacji osób z głęboką intelektualną i wieloraką niepełnosprawnością [The pretence in the education of the people with profound intellectual and multiple disabilities]. Kultura - Społeczeństwo - Edukacja nr 2(18) 2020, Poznań 2020, pp. 83-98, Adam Mickiewicz University Press. ISSN 2300-0422. DOI 10.14746/ kse.2020.18.4.1.
\end{abstract}

The phenomenon of pretence in the Polish educational system of the person with profound intellectual and multiple disabilities (PIMD) will be analized in the context of sociological concept of pretence by Jan Lutynski (1990). The subject of the study was the educational reality of the person with PIMD. Two main questions were formulated. What is the educational reality of the person with PIMD in the micro- and macrosystem context? What is happening in this educational reality? The study was conducted in interpretative paradigm based on quantitative research model using instrumental group case study. The subjects of the study were the people with PIMD (15) and school staff (57). During the study participant observertion, quantitaive deepened interview were used. The symptoms of pretence in education of the person with PIMD on the macrosystem level were visible in the form of inconsistencies in the legal acts regulating the course of education. On the microsystem level the manifestation of the pretence was the phenomenon of the "empty minutes" (i.e. time at school not used for the benefit of the person's development). The results of the study on the macrosystem level suggest lack of the transparency of the legal acts. On the microsystem level the need of developing applicable standards in education of the people with PIMD. 


\section{Wprowadzenie}

Zjawisko pozoru w obszarze edukacji było i jest poruszane przez wielu badaczy zajmujących się problematyką edukacji oraz edukacji specjalnej (por. Kwieciński, 1995; Dudzikowa, 2004, 2013; Zakrzewska-Manterys, 2010; Parys, 2014). Bardzo ciekawą analizę zjawiska pozoru w systemie kształcenia uczniów z niepełnosprawnością przedstawiła Katarzyna Parys (2014). Jej analiza - moim zdaniem - jest pierwszą analizą zjawiska pozoru w obszarze edukacji osób z niepełnosprawnością, również z niepełnosprawnością intelektualną (2014: 29-55). Badaczka analizuje pozór w systemie kształcenia osób z niepełnosprawnością w kontekście socjologicznej koncepcji Jana Lutyńskiego powstałej w latach 70. XX wieku (Lutyński, 1990: 107, za: Parys, 2014), którą zaimplementowała do obszaru pedagogiki specjalnej. Zdaniem tego naukowca „działaniami o charakterze pozornym są wszelkie działania, które - ze względu na swój rzeczywisty przebieg lub bezpośredni cel - są inne, niż na to wyglądają" (Lutyński, 1990: 107, za: Parys, 2014: 30). Lutyński wyróżnia cztery mechanizmy, które prowadzą do zjawiska pozoru w edukacji. Są to:

- mechanizm organizacyjno-decyzyjny polegający na potwierdzeniu i przyjęciu decyzji, które zostały narzucone niezgodnie z obowiązującymi regułami;

- mechanizm aksjologiczny charakteryzujący się działaniami mającymi potwierdzić akceptację oraz realizację wartości, które w rzeczywistości nie są systematycznie wdrażane, mimo że są uznawane;

- mechanizm obowiązkowego wykonawstwa „nierealnych” rozporządzeń przejawiający się wykonaniem zadań niemożliwych do wykonania albo takich, które z uwagi na realizowany faktycznie cel są nieprzydatne;

- mechanizm „rzekomo pragmatyczny” polegający na prowokowaniu działania, które nie prowadzi do rozwiązania trudności, lecz ma potwierdzić zainteresowanie osób odpowiedzialnych za zlikwidowanie trudności; egzemplifikacją tego mechanizmu są sytuacje, w których określona grupa społeczna zgłasza problem wymagający rozwiązania, którego decydenci nie mogą lub, ze znanych im tylko motywów, nie chcą rozstrzygnąć (za: Parys, 2014: 32).

Przedstawione mechanizmy często współwystępują ze sobą, uzupełniają się i wyzwalają określone działania pozorne. Badacze pozoru edukacyjnego zwracają uwagę na jego dynamiczny charakter (por. Dudzikowa, 2004, 2013; Parys, 2014). Co istotne, zjawisko pozoru nie wykazuje tendencji do samowygaszania, wręcz przeciwnie - jedne działania pozorne generują kolejne, skutkiem czego można mówić o samonapędzającej się spirali pozoru (Parys, 2014).

Celem artykułu jest deskrypcja zjawiska pozoru w edukacji osób z głęboką intelektualną i wieloraką niepełnosprawnością (GIWN, w jęz. ang. profound in- 
tellectual and multiple disabilities: PMID)1․ Motywy, które leżą u podłoża eksploracji badawczej pozoru w edukacji osób z GIWN, są dwa. Pierwszy związany jest $\mathrm{z}$ ich stosunkowo krótką obecnością $\mathrm{w}$ polskim systemie edukacji w porównaniu z osobami z niepełnosprawnością intelektualną w stopniu lekkim, umiarkowanym i znacznym oraz $\mathrm{z}$ innymi niepełnosprawnościami². Istotą drugiego jest fakt, że osoba z GIWN z racji współwystępujących niepełnosprawności powodujących prawie zawsze zagrożenie jej życia jest bardzo wymagającym beneficjentem systemu edukacji. Fakt ten może również facylitować zaistnienie zjawiska pozoru w jej obszarze edukacji.

W moim wywodzie dotyczącym zjawiska pozoru w edukacji osób z GIWN będę kolejno omawiała zagadnienia dotyczące pozoru w edukacji ogólnodostępnej, edukacji osób z niepełnosprawnościami oraz edukacji osób z GIWN.

\section{Zjawisko pozoru w edukacji ogólnodostępnej oraz edukacji osób z niepełnosprawnościami}

Przedmiotem moich rozważań nie jest problematyka pozoru w edukacji uczniów uczęszczających do szkół ogólnodostępnych, jednak dla lepszego zrozumienia problemu zjawiska pozoru w edukacji osób z niepełnosprawnością intelektualną warto przytoczyć wyniki badań zebrane w trakcie zrealizowanego przez Kwiecińskiego projektu badawczego, któremu bez wątpienia przysługuje miano

${ }^{1}$ W tekście za obowiązującą przyjmuję definicję niepełnosprawności intelektualnej DSM-5 (American Psychiatric Association, 2016). W tekście dotyczącym głębokiej niepełnosprawności intelektualnej stosuję nazwę, która jest zalecana przez Międzynarodowe Stowarzyszenie na rzecz Badań nad Niepełnosprawnością Intelektualną i Rozwojową (w jęz. ang. International Association for the Scientific Study of Intellectual and Developmental Disabilities: IASSID). Podczas ostatniego Międzynarodowego Kongresu IASSID (Glasgow, 6-9.08.2019) została utworzona odrębna sekcja, w której przez cały czas trwania obrad kongresowych były poruszane zagadnienia dotyczące osoby z głęboką intelektualną i wieloraką niepełnosprawnością z uwzględnieniem kontekstu temporalnego jej życia, tj. okresu jej dzieciństwa, dorosłości oraz późnej dorosłości w kontekście zadań rozwojowych z nimi związanych.

2 Osoba z głęboką niepełnosprawnością intelektualną pojawiła się w polskim systemie edukacji po raz pierwszy w 1997 r. (Dz.U. z 1997 r., nr 14, poz. 76: Rozporządzenie Ministra Edukacji Narodowej z dnia 30 stycznia 1997 roku w sprawie zasad organizowania zajęć rewalidacyjno-wychowawczych dla dzieci i młodzieży upośledzonych umysłowo w stopniu głębokim). Obecnie edukację osób z głęboką niepełnosprawnością intelektualną reguluje Dz.U. z 2013 r., poz. 529 (Rozporządzenie Ministra Edukacji Narodowej z dnia 23 kwietnia 2013 roku w sprawie warunków i sposobu organizowania zajęć rewalidacyjno-wychowawczych dla dzieci i młodzieży upośledzonych umysłowo w stopniu głębokim). O edukacji osób z niepełnosprawnościami, również z GIWN, traktuje Konwencja o prawach osób z niepełnosprawnościami (Dz.U. z 2012 r., poz. 1169, art. 24). 
prekursorskiego, jeżeli chodzi o poruszaną przez badacza problematykę pozoru (Kwieciński, 1995). Jego projekt badawczy został zrealizowany w paradygmacie interpretatywnym $\mathrm{z}$ wykorzystaniem modelu badań jakościowych. Analizie poddano strukturę i jakość wykorzystania czasu 100 lekcji w typowej szkole podstawowej, w klasie ósmej, z wykorzystaniem ukrytej obserwacji uczestniczącej prowadzonej przez ucznia, który został bardzo dobrze przygotowany do prowadzenia protokołu obserwacji pod względem jego rzetelności, dokładności i jasności, oraz minimalnego uwikłania obserwowanych faktów nastawienia i emocji (Kwieciński, 1995: 97). Na podstawie tego badania okazało się, że 24,4 minuty (z każdych 45 minut) przeciętnej lekcji to czas jakkolwiek zorganizowany przez nauczycieli, natomiast 5,5 minuty to czas wykorzystany przez nauczycieli w taki sposób, że jest on pożyteczny dla ucznia (Kwieciński, 1995: 97). Zatem odnosząc się do 100 lekcji, tylko 12,2\% czasu można uznać za czas spędzony wartościowo (Kwieciński, 1995: 96-122). Na podstawie przeprowadzonych badań można stwierdzić, że „[s]zkoła to zorganizowana strata czasu i zorganizowana blokada rozwoju" (Kwieciński, 1995: 97).

W związku z tym, że projekt badawczy był realizowany w paradygmacie interpretatywnym, należy pamiętać, że wyniki badania dotyczyły konkretnej szkoły, w której projekt był realizowany, określonych lekcji, które były obserwowane przez ucznia.

Zdaniem Kwiecińskiego można postawić jednak hipotezę, że tak właśnie mogło być w każdej typowej szkole w odniesieniu do uczniów, którzy od szkoły oczekują intensywnej pracy umysłowej (1995). Należy pamiętać, że powstałe na bazie otrzymanych wyników badań zręby teorii dotyczącej pozoru mają charakter jednostkowy, który w żadnym stopniu nie uprawnia do tworzenia na ich podstawach jakichkolwiek uogólnień (Rubacha, 2008: 329; Kubinowski, 2010; Stake, 2009: 623; Yin, 2015). Mogą być one jednak przydatne podczas dalszych rozważań teoretycznych nad zjawiskiem pozoru oraz wykorzystane do tworzenia kolejnych projektów badawczych.

Na podstawie powyższego studium przypadku uprawnione jest postawienie pytań dotyczących tego, jak wygląda edukacja ucznia z niepełnosprawnością w szkole dla niego przeznaczonej. Czy w szkołach dla osób z niepełnosprawnością można również mówić o pozorze? Odpowiedzią jest w pewnym stopniu analiza zjawiska pozoru w systemie kształcenia uczniów z niepełnosprawnością dokonana przez Katarzynę Parys (2014: 29-53). Jej analiza jest pierwszą analizą zjawiska pozoru w obszarze edukacji osób z niepełnosprawnością. Odwołując się do literatury przedmiotu, badaczka przedstawia przykłady działań pozornych w obszarze edukacji (2014: 33). Z omawianych przez nią działań pozornych wymienię te, które, 
w moim odczuciu, dotyczą również obszaru edukacji osób z głęboką niepełnosprawnością intelektualną. Są to:

- wprowadzanie zmian edukacyjnych wyłącznie w sferze symbolicznej, wdrażanie nowych rytuałów w miejsce starych i stosowanie nowych haseł jedynie symbolizujących oczekiwane zmiany;

- pozorowanie aktywności poznawczej, krytycznego myślenia, kreatywności w działaniach edukacyjnych;

- realizacja idei wszechstronnego rozwoju ucznia na niby;

- praca w szkole jako złudzenie, trening umiejętności unikania pracy prowadzącej do zamierzonych efektów (Parys, 2014: 33).

W kontekście polskiego systemu edukacji dla osób z niepełnosprawnościami badaczka identyfikuje przejawy pozoru w kształceniu integracyjnym i włączającym, sposobie finansowania kształcenia specjalnego, edukacji uzupełniającej w liceach ogólnokształcących dla uczniów z niepełnosprawnością intelektualną oraz ofercie podręcznikowej dla uczniów z niepełnosprawnościami (2014: 34-49).

Warto w tym miejscu przytoczyć bardzo krytyczną ocenę szkolnictwa dla osób $\mathrm{z}$ niepełnosprawnością intelektualną $\mathrm{w}$ stopniu umiarkowanym i znacznym dokonaną przez Elżbietę Zakrzewską-Manterys (2010). Badaczka nie pisze wprost o pozorze w edukacji osób z niepełnosprawnością intelektualną, ale można o nim wnioskować na podstawie dokonanej przez nią deskrypcji szkolnictwa dla osób z niepełnosprawnością intelektualną w stopniu umiarkowanym i znacznym.

Zakrzewska-Manterys w swoich wywodach nawiązuje do koncepcji Pierre’a Bourdieu (2006), który - podobnie jak Emil Durkheim (2006) - w pedagogice widział klucz do reprodukcji systemów społecznych (2010). Odwołując się do kategorii pojęciowych Bourdieu (2006), dowodzi, że w przypadku „pedagogiki specjalnej i stworzonej na jej podstawach szkoły specjalnej widoczne jest mechaniczne i całkowicie bezprzedmiotowe naśladowanie systemu szkolnego" (2010: 165). Zdaniem badaczki system szkolnictwa specjalnego funkcjonuje tak, jak gdyby był podobny do systemu ogólnego, ale był tylko trochę prostszy (2010: 165).

Ocena, jaką stawia Zakrzewska-Manterys szkole dla osób z umiarkowaną i znaczną niepełnosprawnością intelektualną, jest bardzo krytyczna. Jej zdaniem szkoła taka jest „zbudowana z papier mache sceny, na której w różny sposób odgrywa się zabawę w szkołę, bez żadnych strukturalnych z nią podobieństw" (2010: 166) i jest również „wydmuszką, pustą formą, skorupką otaczającą niczym niewypełnione miejsce" (2010: 167). Niejawność podstaw szkoły specjalnej polega na podtrzymywaniu tajemnicy, „że szkoła ta nie przygotowuje do życia [...]. Szkoła specjalna może być instytucją opiekuńczą, kulturalną, forum spotkań towarzyskich, miejscem pożytecznego spędzania czasu, miejscem, w którym uczy się nie- 
których technik szkolnych i zdobywa wiedzę w niektórych dziedzinach. To bardzo dużo, ale jeszcze za mało, by szkołę specjalną nazwać instytucją edukacyjną [wyróż. D.K.] [...]. To, czego uczą szkoły specjalne, to wiedza na temat jak być kompetentnym, upośledzonym umysłowo członkiem społeczeństwa" (Zakrzewska-Manterys, 2010: 167) ${ }^{3}$.

\section{Zjawisko pozoru w edukacji osób z głęboką intelektualna i wieloraką niepelnosprawnością}

Jak zatem przedstawia się zjawisko pozoru w odniesieniu do edukacji osób z głęboką intelektualną i wieloraką niepełnosprawnością? Jaka jest jego specyfika?

Zanim spróbuję odpowiedzieć na powyższe pytania, scharakteryzuję krótko zrealizowany projekt badawczy, który dotyczył rzeczywistości edukacyjnej osoby z głęboką niepełnosprawnością intelektualną. Jego przedmiotem nie było zjawisko pozoru, ale w trakcie realizacji projektu poznałam dane będące jego egzemplifikacją (Kopeć, 2013).

Przedmiotem projektu badawczego ${ }^{4}$ była rzeczywistość edukacyjna osoby z głęboką intelektualną i wieloraką niepełnosprawnością, którą rozumiałam jako jej przestrzeń w polskim systemie edukacji, która jest jej zagwarantowana aktami prawnymi, w której zachodzą procesy związane z edukacją, pielęgnacją i terapią. Wiodące dla mnie były dwa pytania:

${ }^{3}$ Przyznaję, że jako pedagog specjalny bardzo rezonuję na tak krytyczną deskrypcję rzeczywistości edukacyjnej szkoły specjalnej. Bez wątpienia motywuje ona do podjęcia projektów badawczych, których wyniki pokazałyby rzeczywisty obraz szkoły dla osób z umiarkowaną i znaczną niepełnosprawnością intelektualną w kontekście oferty edukacyjnej. Warto w tym miejscu wspomnieć o projekcie badawczym dotyczącym normalizacji środowiska społecznego osób z niepełnosprawnością intelektualną zrealizowanym przez Amadeusza Krausego, Sylwię Nosarzewską i Agnieszkę Żytę w latach 2007-2008 (Krause, Żyta, Nosarzewska, 2010). Projekt był realizowany na terenie województwa warmińsko-mazurskiego, w którym występował znaczny odsetek bezrobocia. Można było zauważyć także duże nasilenie zjawiska niepełnosprawności. Badania były realizowane w ramach modelu ilościowo-jakościowego (sondaż diagnostyczny, wywiad biograficzno-narracyjny). Zastosowano warstwowo-losowy dobór próby badawczej, która liczyła 128 osób (w tym 26 osób z niepełnosprawnością intelektualną w stopniu lekkim). Na podstawie otrzymanych wyników badań stwierdzono, że początek problemów badanych osób leży w ich przeszłości edukacyjnej, bez względu na przebytą przez nich ścieżkę edukacyjną, tzn. bycie uczniem szkoły specjalnej czy też szkoły integracyjnej (Krause, Żyta, Nosarzewska, 2010: 172-173). Zauważono, że osoba z niepełnosprawnością intelektualną jest postrzegana jako ta, która „wyłącznie potrzebuje pomocy, niesamodzielna, niezdolna do autonomicznych wyborów, mająca ograniczoną podmiotowość i decyzyjność (Krause, Żyta, Nosarzewska, 2010: 180).

${ }^{4}$ Szczegółowy opis projektu badawczego został przedstawiony w pozycji Kopeć, 2013. 
- Jaka jest rzeczywistość edukacyjna osoby z głęboką intelektualną i wieloraką niepełnosprawnością w kontekście mikrosystemu, mezosystemu, egzosystemu, makrosystemu i chronosystemu?

- Co się dzieje w rzeczywistości edukacyjnej osoby z głęboką intelektualną i wieloraką niepełnosprawnością na poziomie mikrosystemu, mezosystemu, egzosystemu, makrosystemu i chronosystemu?

Badanie $^{5}$, w ramach którego zebrałam materiał empiryczny, zostało przeprowadzone w paradygmacie interpretatywnym z wykorzystaniem modelu badań jakościowych. Podmiotami badania były:

- osoby z głęboką intelektualną i wieloraką niepełnosprawnością - uczestnicy zajęć rewalidacyjno-wychowawczych (15); obserwacja uczestnicząca; towarzyszyłam im w ramach obserwacji uczestniczącej przez cały czas ich pobytu na zajęciach rewalidacyjno-wychowawczych, od chwili opuszczenia przez nich domu rodzinnego do momentu powrotu do niego;

- wszyscy pracownicy szkoły, którzy wchodzili w jakąkolwiek relację z podmiotami badania $\mathrm{z}$ racji pełnionej przez siebie funkcji zawodowej: dyrektor szkoły (5 osób), nauczyciele prowadzący zajęcia rewalidacyjno-wychowawcze (24 osoby), odpowiedzialni za usprawnianie ruchowe osób z głęboką niepełnosprawnością intelektualną w ramach zajęć rewalidacyjno-wychowawczych (6 osób), nauczyciele świetlicy (10 osób) i osoby pomagające (12 osób); przeprowadziłam z nimi wywiad jakościowy częściowo kierowany skoncentrowany na problemie.

Jestem świadoma, że w wyniku realizacji mojego projektu badawczego, którego rdzeniem było zbiorowe instrumentalne studium przypadku, zmierzałam do stworzenia jednostkowej teorii szeroko rozumianej rzeczywistości edukacyjnej osoby z głęboką niepełnosprawnością intelektualną (Kopeć, 2013).

Moim zdaniem u podłoża zjawiska pozoru w obszarze edukacji osoby z głęboką intelektualną i wieloraką niepełnosprawnością leżą przede wszystkim dwa mechanizmy implikujące pozór w obszarze edukacji wspomniane przez Parys (2014). Są nimi mechanizm aksjologiczny ${ }^{6}$ oraz mechanizm rzekomo pragma-

${ }^{5}$ Projekt badawczy był realizowany od kwietnia 2010 roku do listopada 2011 roku. Odwołując się do osobistego doświadczenia opiekuna praktyki studenckiej w oddziałach rewalidacyjno-wychowawczych dla osób z głęboką intelektualną i wieloraką niepełnosprawnością, widzę konieczność realizacji projektu badawczego, który będzie dotyczył pozoru w edukacji tej grupy osób. Analizując dokumentację z praktyki studenckiej, mam bowiem poczucie, a nawet pewność, że zjawisko pozoru w edukacji osób z głęboką intelektualną i wieloraką niepełnosprawnością jest cały czas obecne i domaga się pogłębionej eksploracji badawczej.

${ }^{6} \mathrm{~W}$ kontekście tego mechanizmu należy pamiętać o języku, a przede wszystkim o jego „nieprzejrzystych aspektach”. „Ludzie często nie zdają sobie sprawy ani z ideologicznego ładunku okreś- 
tyczny (Parys, 2014: 32). Przejawy zjawiska pozoru w edukacji osoby z głęboką intelektualną i wieloraką niepełnosprawnością będę przedstawiała tylko z poziomu mikrosystemu ${ }^{7}$ rozumianego zgodnie $\mathrm{z}$ paradygmatem systemowo-ekologicznym i przynależnej do niego bioekologicznej teorii systemów Urie Bronfenbrennera (Bronfenbrenner, 1979; Bronfenbrenner, Moris, 1998; Schalock i in., 2010: 17-18; Schalock i in., 2010: 176).

Widocznym przejawem pozoru na poziomie mikrosystemu jest zjawisko „pustych minut” ${ }^{8}$ pojawiające się podczas realizacji zajęć rewalidacyjno-wychowawczych. Jego istota tkwi w tym, że czas, który w założeniu powinien być dystrybuowany w taki sposób, by:

- po pierwsze, przekazywać wiedzę osobie z głęboką intelektualną i wieloraką niepełnosprawnością (zajęcia rewalidacyjno-wychowawcze odbywają się przecież w ramach systemu edukacji);

- po drugie, wspierać rozwój osoby z głęboką niepełnosprawnością intelektualną,

nie zostaje wykorzystany do poszerzania jej wiedzy oraz wspierania jej rozwoju, lecz zostaje bezpowrotnie zaprzepaszczony (por. Kwieciński, 1995: 96-122). Należy pamiętać, że dla ucznia z głęboką intelektualną i wieloraką niepełnosprawnością, którego stan zdrowia skutkuje częstą absencją w szkole, sytuacje, w których czas w trakcie zajęć zostaje bezpowrotnie zaprzepaszczony, muszą budzić poważny niepokój i sprzeciw.

lonych sposobów używania języka, ani z leżących u jego podłoża relacji władzy" (Fairclough, Wodak, 2006: 1047; por. Klemperer, 1992; Kopeć, 2013: 155).

${ }^{7}$ Oczywiście nie wolno zapominać o wpływie zjawisk dziejących się na poziomie makrosystemu na mikrosystem. Mam tu przede wszystkim na uwadze ustanowione na poziomie makrosystemu akty prawe regulujące edukację osoby z głęboką intelektualną i wieloraką niepełnosprawnością, a przede wszystkim Rozporządzenie Ministra Edukacji Narodowej z dnia 23 kwietnia 2013 r. w sprawie warunków i sposobu organizowania zajęć rewalidacyjno-wychowawczych dla dzieci i młodzieży z upośledzeniem umysłowym w stopniu głębokim (Dz.U. z 2013 r., poz. 529). Po ich dogłębnej analizie można skonstatować następujące niespójności dotyczące edukacji osób z głęboką intelektualną i wieloraką niepełnosprawnością, które facylitują zaistnienie zjawiska pozoru na poziomie mikrosystemu. Są nimi między innymi: 1) wprowadzenie terminu: zajęcia rewalidacyjno-wychowawcze, które są rozumiane jako obowiązkowa oferta edukacyjna dla osoby z głęboką niepełnosprawnością intelektualną, a nie lekcja; 2) przyznanie osobie z głęboką niepełnosprawnością intelektualną statusu uczestnika zajęć rewalidacyjno-wychowawczych, a nie ucznia, pomimo konieczności realizacji przez niego obowiązku szkolnego; 3) brak podstawy programowej, jak również zakresu treści nauczania i wychowania oraz wyodrębnienia konkretnych form zajęć (Kopeć, 2013: 150-169).

${ }^{8}$ Określenie, które pojawiło się w wypowiedzi podmiotu badania biorącego udział w moim projekcie badawczym - kod in vivo (por. Charmaz, 2009: 76-79). Zentel opisujący podobne zjawisko występujące w edukacji osób z niepełnosprawnością intelektualną używa określenia „luka” (w jęz. niem. die Lücke) (2015). 
Uzasadnione jest zatem pytanie o konkretną egzemplifikację zjawiska „pustych minut” widoczną w przebiegu zajęć rewalidacyjno-wychowawczych. Uczeń ${ }^{9}$ z głęboką intelektualną i wieloraką niepełnosprawnością, jak już wspominałam, z racji współwystępujących niepełnosprawności i schorzeń somatycznych jest bardzo wymagającym odbiorcą oferty edukacyjnej, u której podłoża musi leżeć uwzględnienie jego stanu psychofizycznego oraz jego aktualnych psychofizycznych zasobów. Dlatego też w odniesieniu do edukacji uczniów z głęboką intelektualną i wieloraką niepełnosprawnością Weiß mówi o swoistej triadzie oddziaływań, które muszą w jej trakcie się pojawić (2012, za: Zentel, 2015). Są nimi procesy związane z przekazywaniem wiedzy, terapią i pielęgnacją ${ }^{10}$ (2012, za: Zentel, 2015). Mając na uwadze wyróżnioną przez Weißa triadę (przekazywanie wiedzy, terapia, pielęgnacja), postaram się przedstawić przejawy zjawiska „pustych minut” w wyróżnionych przez niego obszarach, uwzględniając całodzienny pobyt ucznia w szkole ${ }^{11}$ (por. Zentel, 2015).

\section{Przejawy zjawiska „pustych minut” w obszarze pielęgnacji}

Przejawy zjawiska „pustych minut” w obszarze pielęgnacji (tj. przede wszystkim spożywanie posiłku, czynności toaletowe) w przebiegu zajęć rewalidacyjno-wychowawczych można analizować w dwóch kontekstach: w pierwszym, który dotyczy tylko czynności pielęgnacyjnych, i w drugim, w którym czynności pielęgnacyjne stają się swoistym „rdzeniem” zajęć rewalidacyjno-wychowawczych, niestety kosztem zajęć edukacyjnych (przekazywanie wiedzy) oraz zajęć terapeutycznych, których oferta również powinna się pojawić w ramach zajęć rewalidacyjno-wychowawczych. Kolejno omówię każdy z nich, odwołując się do zgromadzonego materiału empirycznego, który będę analizowała z perspektywy podmiotu badania (Kopeć, 2013: 227-247).

9 Świadomie pomijam zalecane przez rozporządzenie określenie „uczestnik”, a stosuję „uczeń” (Dz.U. z 2013 r., poz. 529).

${ }_{10}$ W jęz. niem. Unterricht, Therapie Pflege (Weiß, 2012, za: Zentel, 2015).

${ }^{11}$ Zentel, analizując niemiecką rzeczywistość edukacyjną uczniów z głęboką intelektualną i wieloraką niepełnosprawnością, identyfikuje luki (zjawisko „pustych minut”) w przebiegu: konkretnej lekcji i/lub konkretnych zajęć, całodziennego pobytu ucznia w szkole, całorocznego pobytu ucznia w szkole, a także w trakcie realizacji konkretnych treści kształcenia, które powinny być wspólne dla wszystkich uczniów. Wyróżnione przez badacza kryteria dotyczą edukacji, która ma miejsce w ramach edukacji włączającej, tzn. w której uczeń z głęboką intelektualną i wieloraką niepełnosprawnością uczęszcza do szkoły ogólnodostępnej (2015, por. Bauersfeld, 2015: 43-59). 
W obszarze pielęgnacji zjawisko „pustych minut” spowodowane jest zazwyczaj przedłużającym się czasem wykonywania czynności pielęgnacyjnych, który zawsze uruchamia "efekt domina czasowego" mającego odzwierciedlenie w ciągu całego dnia pobytu podmiotu badania w szkole. Z perspektywy podmiotu badania przedłużanie czynności pielęgnacyjnych oznaczało zawsze tracenie czasu na bezproduktywne czekanie na swoją kolej uczestnictwa w czynnościach pielęgnacyjnych lub czekanie, aż wszystkie osoby z zespołu rewalidacyjno-wychowawczego zakończą swoje czynności pielęgnacyjne. Czas oczekiwania podczas jednorazowej czynności opiekuńczej wahał się od 10 do 30 minut (Kopeć, 2013: 230-240). Zważywszy na to, że czas pobytu ucznia z głęboką intelektualną i wieloraką niepełnosprawnością w szkole w ciągu dnia wynosi zazwyczaj cztery godziny (por. Dz.U. z 2013 r., poz. 529, \$ 10), a czynności pielęgnacyjne się powtarzają, strata czasu jest rzeczywiście duża. Potęguje ją jeszcze bardziej świadomość tego, że ma ona bardzo konkretny wpływ na skrócenie i/lub całkowite pomijanie zajęć edukacyjnych i terapeutycznych przewidzianych podczas pobytu ucznia $\mathrm{z}$ głęboką intelektualną i wieloraką niepełnosprawnością w szkole. W ten sposób czynności pielęgnacyjne zaczynają przeważać podczas całego pobytu w szkole i stają się, o czym już wspominałam, osią, wokół której organizowane są zajęcia rewalidacyjno-wychowawcze. „Celebracji czynności pielęgnacyjnych” sprzyja niewątpliwie stereotypowe myślenie o uczniu z głęboką intelektualną i wieloraką niepełnosprawnością przede wszystkim jako o „obiekcie” oddziaływań pielęgnacyjnych $\mathrm{z}$ racji schorzeń współwystępujących $\mathrm{z}$ niepełnosprawnością intelektualną $\mathrm{w}$ stopniu głębokim ${ }^{12}$. Zgadzam się $\mathrm{w}$ pełni ze stwierdzeniem, że czynności pielęgnacyjne w pracy z uczniem z głęboką intelektualną i wieloraką niepełnoprawnością są bardzo ważne i mogą być wykorzystywane do edukacji i terapii osoby (por. Fröhlich, 1991; Finnie, 1994; Fröhlich, 1998; Fröhlich, 2015). Nie mogą jednak stać się jedynymi aktywnościami, które są oferowane uczniom w ramach zajęć rewalidacyjno-wychowawczych. Mam jednak świadomość, że w porównaniu z zajęciami edukacyjnymi i terapeutycznymi są najłatwiejsze do zaoferowania uczniowi z głęboką intelektualną i wieloraką niepełnosprawnością.

${ }_{12}$ Maciej Baraniewicz w swoim wystąpieniu pt. Standardy opieki, edukacji i terapii osób $z$ głęboką intelektualna $i$ wieloraka niepełnosprawnością na konferencji poświęconej podmiotowości osób z głęboką intelektualną i wieloraką niepełnosprawnością, Poznań 2019, przytoczył wypowiedzi nauczycieli pracujących z uczniami z GIWN dotyczące oferty proponowanej uczniom w ramach zajęć rewalidacyjno-wychowawczych. Wśród udzielonych odpowiedzi przeważała oferta związana z opieką i terapią. 


\section{Przejawy zjawiska „pustych minut” w obszarze terapii}

Zajęcia o charakterze terapeutycznym ${ }^{13}$ są drugim po pielęgnacji rodzajem zajęć, który przeważa w ofercie edukacyjnej (jeżeli tak można ją nazwać) ucznia z głęboką intelektualną i wieloraką niepełnosprawnością ${ }^{14} \mathrm{~W}$ ramach zajęć rewalidacyjno-wychowawczych w polskim systemie edukacji. Zjawisko „pustych minut” można analizować w kontekście dystrybucji czasu w dwóch wymiarach:

- instytucjonalnym, uwzględniającym perspektywę instytucji, w której odbywają się zajęcia rewalidacyjno-wychowawcze,

- jednostkowym, uwzględniającym perspektywę ucznia z głęboką intelektualną i wieloraką niepełnosprawnością (Kopeć, 2013: 244-247).

Należy pamiętać, że analizowanie czasu przeznaczonego na zajęcia terapeutyczne w kontekście wymiaru instytucjonalnego pokazuje jedynie, jaki czas instytucja, jaką jest szkoła, bądź inna placówka edukacyjna odpowiedzialna za organizację zajęć rewalidacyjno-wychowawczych na nie przeznacza. Czas trwania całego bloku zajęć rewalidacyjno-wychowawczych jest dokładnie określony rozporządzeniem ministerialnym regulującym realizację zajęć rewalidacyjno-wychowawczych (Dz.U. z 2013 r., poz. 526, \$ 10). Natomiast czas rzeczywisty, który będzie przeznaczony na realizację zajęć terapeutycznych sensu stricto, będzie zależał od harmonogramu zajęć rewalidacyjno-wychowawczych na terenie szkoły / placówki edukacyjnej oraz formy organizacyjnej konkretnych zajęć (wymiar instytucjonalny) (por. Kwieciński, 1995: 96-122; Kopeć, 2013: 246). Zatem, by stwierdzić, czy czas przeznaczony na realizację zajęć terapeutycznych w ramach zajęć rewalidacyjno-wychowawczych był rzeczywiście wykorzystany w taki sposób, by wspierać rozwój ucznia z głęboką intelektualną i wieloraką niepełnosprawnością, nie można poprzestać tylko na analizie tygodniowego czy dziennego harmonogramu zajęć rewalidacyjno-wychowawczych. Należy bowiem na wymiar instytucjonalny nałożyć jednostkowy (tzn. analizować czas zajęć z perspektywy ucznia z głęboką intelektualną i wieloraką niepełnosprawnością), i to on (wymiar jednostkowy) będzie wskaźnikiem jakości wykorzystanego czasu. Oznacza to konieczność traktowania informacji o tym, że np. zajęcia ze stymulacji sensorycznej ${ }^{15}$ trwają 45 minut, tyl-

${ }^{13}$ Można wśród nich wyróżnić między innymi następujące rodzaje zajęć: stymulację bazalną, snoezellen, metodę integracji sensorycznej, metodę M. i Ch. Knillów, metodę ruchu rozwijającego Weroniki Sherborne.

${ }^{14}$ Lamers podkreśla, że im głębszy stopień niepełnosprawności intelektualnej, tym mniej przekazywanej wiedzy na korzyść opieki i terapii (2000).

${ }^{15}$ Podana nazwa zajęć pochodzi z tygodniowego rozkładu zajęć, który był analizowany w trakcie trwania projektu badawczego. 
ko jako takiej, która dotyczy czasu przeznaczonego na zajęcia ze stymulacji sensorycznej dla całego zespołu rewalidacyjno-wychowawczego. W kontekście wymiaru jednostkowego, z perspektywy konkretnej osoby z głęboką intelektualną i wieloraką niepełnosprawnością „konkretne zajęcia nie będą trwały 45 minut, jak sugeruje harmonogram, a jedynie tyle czasu, ile jest w stanie poświęcić nauczyciel je prowadzący, który musi czas zajęć podzielić niejako na wszystkich uczestników zajęć rewalidacyjno-wychowawczych, których maksymalnie może być czterech ${ }^{16}$ (por. Dz.U. z 2013 r., \$ 9.2). A więc w opisanej powyżej sytuacji dla konkretnej osoby z głęboką intelektualną i wieloraką niepełnosprawnością będzie to w przybliżeniu tylko 11,3 minut zajęć, a nie 45 minut” (Kopeć, 2013: 246).

Dla zajęć terapeutycznych realizowanych w ramach zajęć rewalidacyjno-wychowawczych bardzo ważny jest cel, u którego podłoża winny leżeć rzeczywiste potrzeby ucznia $\mathrm{z}$ głęboką intelektualną i wieloraką niepełnosprawnością oraz wiedza nauczyciela odpowiedzianego za ich przebieg. Osobiście bardzo rezonuję na maksymę Yogi Berrary: „Jeśli nie wiesz, dokąd idziesz, musisz bardzo uważać, bo możesz tam nie dojść" (2015: 163). Brak jasnego, konkretnego celu zajęć ugruntowanego w wiedzy nauczyciela facylituje pojawienie się zjawiska "pustych minut”. Na wagę wiedzy i jednocześnie na jej brak zwraca uwagę jeden z podmiotów badania, który bierze udział w projekcie badawczym. „Brakuje mi takiej twardej wiedzy u nauczycieli, żeby oni widzieli, po co to robią, dlaczego to robią, dlaczego temu dziecku proponują to, a temu tamto. Czasami to jest wręcz przerażające, że ludzie nie potrafią odpowiedzieć na te pytania. Stosują metody, bo je znają, albo trochę znają, ale czy to jest rzeczywiście dobre dla dziecka, tego już nie wiedzą [P23]" (Kopeć, 2013: 288-289).

\section{Przejawy zjawiska „pustych minut” w obszarze przekazywania wiedzy}

Jak już wspomniałam, celem realizacji mojego projektu badawczego nie było zjawisko pozoru w rzeczywistości edukacyjnej osoby z głęboką intelektualną i wieloraką niepełnosprawnością. Identyfikowałam je niejako przy okazji, opisując jej rzeczywistość edukacyjną. Kiedy dzisiaj analizuję zebrany materiał badawczy, muszę stwierdzić, że w obszarze przekazywania wiedzy w odniesieniu do zajęć

${ }^{16}$ Widoczna jest zatem zależność zachodząca pomiędzy aktami prawnymi ustanowionymi na poziomie makrosystemu a zjawiskami zachodzącymi na poziomie mikrosystemu. Uprawnione jest postawienie tezy, że akty prawne facylitują pojawienie się zjawiska "pustych minut” na poziomie mikrosystemu. 
rewalidacyjno-wychowawczych uzasadnione jest nie tyle mówienie o zjawisku „pustych minut”, ale raczej o „syndromie pustki edukacyjnej”. Można ją scharakteryzować jako zazwyczaj całkowity brak wprowadzania treści edukacyjnych do zajęć rewalidacyjno-wychowawczych (por. Lamers, 2000; Baraniewicz, 2019). Odnosząc się do triady edukacyjnej Weißa (za: Zentel, 2015), można powiedzieć, że w przebiegu zajęć rewalidacyjno-wychowawczych wypełniony treściami jest przede wszystkim (a czasami tylko!) obszar związany z terapią i pielęgnacją. „Syndrom pustki edukacyjnej” konfrontuje pedagogów specjalnych z brakiem treści edukacyjnych $\mathrm{w}$ pracy z osobą z głęboką intelektualną i wieloraką niepełnosprawnością. Implikuje jednocześnie ważkie pytania dotyczące edukacji sensu stricto oferowanej osobie; formy, którą powinna przyjąć, by z perspektywy osoby miała sens; treści kształcenia. „Syndrom pustki edukacyjnej” unaocznia dyskryminację osoby z głęboką intelektualną i wieloraką niepełnosprawnością w polskim systemie edukacji ${ }^{17}$.

\section{Refleksje końcowe}

Gdzie zatem można upatrywać uwarunkowań zjawiska „pustych minut”, które pojawia się w czasie realizacji zajęć rewalidacyjno-wychowawczych? Myślę, że można wyróżnić ich dwie nadrzędne kategorie, a mianowicie: instytucjonalne i osobowe (Kopeć, 2013: 287). Czynniki instytucjonalne warunkujące zjawisko „pustych minut" można rozpatrywać na dwóch poziomach: makro- i mikrosystemu. Na poziomie makrosystemu jest to między innymi Rozporządzenie Ministra Edukacji Narodowej w sprawie zasad organizowania zajęć rewalidacyjno-wychowawczych dla dzieci i młodzieży upośledzonych w stopniu głębokim z dnia 23 kwietnia 2013 r. (Dz.U. z 2013 r., poz. 529). Na poziomie mikrosystemu jest to tygodniowy plan zajęć rewalidacyjno-wychowawczych obowiązujący w danej szkole i/lub placówce edukacyjnej. Powinny być w nim szczegółowo przedstawione wszystkie czynności ${ }^{18}$, które w ciągu dnia będą oferowane uczniowi z głęboką intelektualną i wieloraką niepełnosprawnością. Czynniki osobowe warunkujące zjawisko „pustych minut" związane są z osobą pracującą z uczestnikiem zajęć rewalidacyjno-wychowawczych. To od jej responsywności, umiejętności mentalizowania oraz wiedzy

\footnotetext{
${ }^{17}$ W zapełnianiu „pustki edukacyjnej” pomocna okazuje się koncepcja dwóch niemieckich pedagogów specjalnych: Wolfganga Lamersa i Norberta Heinena - edukacja z ForMatem (2000).

${ }^{18} \mathrm{~W}$ dziennym planie dnia powinien być również uwzględniony czas dojścia do sali, w której odbywają się zajęcia, dokładny czas czynności pielęgnacyjnych, odpoczynku.
} 
będzie zależała forma zajęć rewalidacyjno-wychowawczych pod względem treściowym, strukturalnym i organizacyjnym (Kopeć, 2013: 287-288) ${ }^{19}$.

Myślenie o tym, że zjawisko pozoru uda się całkowicie z obszaru edukacji osób z głęboką intelektualną niepełnosprawnością wyeliminować, jest ułudą - zawsze będzie ono powiązane z procesami toczącymi się na poziomie chronosystemu, uwikłane, w większym bądź mniejszym stopniu, w system polityczny państwa na poziomie makrosystemu. Nie zwalnia to jednak osoby pracującej w obszarze edukacji osób z głęboką niepełnosprawnością intelektualną z obowiązku ciągłej demistyfikacji zjawiska pozoru. Jest to zadanie stojące przed każdym pedagogiem specjalnym - praktykiem i teoretykiem. Polega na zapobieganiu temu zjawisku w edukacji i jego identyfikowaniu. Na poziomie makrosystemu to dbałość o jasność aktów prawnych i ich precyzję oraz niestygmatyzujący język, położenie nacisku w nich na konieczność uwzględniania w ramach zajęć rewalidacyjno-wychowawczych na równych zasadach pielęgnacji, terapii i edukacji. Na poziomie mikrosystemu to przede wszystkim:

- konstruowanie bardzo szczegółowego planu pracy (tygodniowego, dziennego) osoby z głęboką intelektualną i wieloraką niepełnosprawnością w kontekście jej rzeczywistych potrzeb i zasobów z uwzględnieniem opieki, terapii i edukacji;

- praca $w$ relacji oraz zwrócenie uwagi na ochronne, stabilne relacje w środowisku obejmującym podstawowe służby i wsparcie rodziny w celu zapewnienia bezpieczeństwa i ochrony (Greenspan, Wieder, 2014: 261);

- identyfikowanie obszarów facylitujących zjawisko pozoru w osobie pedagoga specjalnego zgodnie ze stwierdzeniem: „Niech na świecie pojawi się zmiana i niech zacznie się ona od Ciebie" (Powell, Cooper, Hoffman, Marvin, 2015: 260).

\section{Bibliografia}

American Psychiatric Association (2016), Kryteria diagnostyczne z DSM-5. Desk Reference, Wrocław. Baraniewicz M. (2019), Standardy opieki, edukacji i terapii osób z głębokq intelektualna i wieloraką niepetnosprawnością. Referat wygłoszony na konferencji poświęconej podmiotowości osób z głęboką intelektualną i wieloraką niepełnosprawnością, Poznań.

Bauersfeld S. (2015), Treści kształcenia a głęboka niepetnosprawność - proces planowania zajęć, w: Edukacja bazalna. Nauczanie i terapia dzieci z glęboką niepetnosprawnością, red. A. Fröhlich, Sopot, s. 43-61.

${ }^{19}$ Oczywiście uczeń z głęboką intelektualną i wieloraką niepełnosprawnością również będzie miał wpływ na zajęcia rewalidacyjno-wychowawcze, ale całkowitą odpowiedzialność za ich przebieg zawsze będzie ponosił pedagog specjalny. 
Bourdieu P. (2006), Medytacje pascaliańskie, Warszawa.

Bronfenbrenner U. (1979), The Ecology of Human Development, Cambridge.

Bronfenbrenner U., Morris P.A. (1998), The ecology of developmental processes, w: Handbook of child psychology, vol. 1: Theoretical models of human development, ed. R.M. Lerner, New York, pp. 993-1028.

Charmaz K. (2009), Teoria ugruntowana. Praktyczny przewodnik po analizie jakościowej, przeł. B. Komorowska, Warszawa.

Dudzikowa M. (2004), Mit o szkole jako miejscu wszechstronnego rozwoju ucznia. Eseje etnopedagogiczne, Kraków.

Dudzikowa M. (2013), Działania pozorne w edukacji jako palacy problem. Wprowadzenie do książ$k i$, w: Sprawcy i/lub ofiary działań pozornych w edukacji szkolnej, red. K. Knasiecka-Falbierska, Kraków.

Durkheim E. (2006), Samobójstwo. Studium z socjologii, Warszawa.

Fairclough N., Wodak R. (2006), Krytyczna analiza dyskursu, przeł. A. Ostolski, w: Wspótczesne teorie socjologiczne, t. 2, red. A. Jasińska-Kania, L.M. Nijakowski, J. Szacki, M. Ziółkowski, Warszawa, s. 1047-1061.

Fröhlich A. (1998), Stymulacja od podstaw, przeł. Z. Białek, L. Czarkowska, A. Firkowska-Mankiewicz, Warszawa.

Fröhlich A. (red.) (2015), Edukacja bazalna. Nauczanie i terapia dzieci z głęboka niepełnosprawnościa, Sopot.

Greenspan I.S., Wieder S. (2014), Dotrzeć do dziecka z autyzmem. Jak pomóc dzieciom nawiązać relacje, komunikować się i myśleć. Metoda Floortime, przeł. D. Braithwaite, Kraków.

Heinen N., Lamers W. (2006), Bildung mit ForMat. Impulse für enie veränderte Unterrichtspraxis mit Schülerinnen und Schülern mit (schwerer) Behinderung, w: Basale Stimulation. Kritsch-konstruktiv, eds. L. Desiree, W. Lamers, N. Heinen, Düsseldorf, pp. 141-205.

Klemperer V. (1992), LTI. Notatnik filologa, przeł. M. Stroińska, Toronto.

Kopeć D. (2013), Rzeczywistość (nie)edukacyjna osoby z głęboka niepetnosprawnością intelektualna. Zbiorowe instrumentalne studium przypadku, Poznań.

Krause A., Żyta A., Nosarzewska S. (2010), Normalizacja środowiska społecznego osób z niepelnosprawnościq intelektualną, Toruń.

Kubinowski D. (2010), Jakościowe badania pedagogiczne. Filozofia. Metodyka. Ewaluacja, Lublin.

Kwieciński Z. (1995), Praca w szkole jako złudzenie, w: Socjopatologia edukacji, red. Z. Kwieciński, Olecko, s. 96-122.

Lamers W. (2000), Goethe und Matisse für Menschen mit einer schwerer Behinderung, w: Geistigbehindertenpädagogik als Begegnung, eds. N. Heinen, W. Lamers, Düsseldorf, pp. 177-208.

Parys K. (2014), Zjawisko pozoru w systemie kształcenia uczniów niepełnosprawnych - próba identyfikacji i propozycje rozwiązań, „Interdyscyplinarne Konteksty Pedagogiki Specjalnej”, nr 4, s. 29-56.

Powel B., Cooper G., Hoffman K., Marvin B. (2015), Krąg ufności. Interwencja wzmacniająca przywiązanie we wczesnych relacjach rodzic - dziecko, przeł. R. Andruszko, Kraków.

Rubacha K. (2008), Metodologia badań nad edukacją, Warszawa.

Schalock R.L., Borhwick-Duffy S.A., Luckasson R. i in. (2010), Intellectual Disability. Definition, Classification and Systems of Supports. The AAIDD Ad Hoc Committee on Terminology and Classification, Washington.

Stake R.E. (2009), Jakościowe studium przypadku, przeł. M. Sałkowska, w: Metody badań jakościowych, t. 1, red. N.K Denzin, Y.S. Lincoln, Warszawa, s. 623-655. 
Yin R.K. (2015), Studium przypadku w badaniach naukowych. Projektowanie i metody, Kraków.

Zakrzewska-Manterys M. (2010), Upośledzeni umysłowo. Poza granicami człowieczeństwa, Warszawa. Zentel P. (2015), Schülerinnen und Schüler mit schwerer und mehrfacher Behinderung in der Inklusion. Referat wygłoszony na seminarium naukowym pt. Osoba z głębokq niepełnosprawnościq intelektualna w systemie edukacji, Poznań.

\section{Akty prawne}

Dz.U. z 1997 r., nr 14, poz. 76. Rozporządzenie Ministra Edukacji Narodowej z dnia 30 stycznia 1997 r. w sprawie zasad organizowania zajęć rewalidacyjno-wychowawczych dla dzieci i młodzieży upośledzonych umysłowo w stopniu głębokim.

Dz.U. z 2012 r., poz. 1169. Konwencja o prawach osób z niepełnosprawnościami.

Dz.U. z 2013 r., poz. 529. Rozporządzenie Ministra Edukacji Narodowej z dnia 23 kwietnia 2013 r. w sprawie warunków i sposobu organizowania zajęć rewalidacyjno-wychowawczych dla dzieci i młodzieży upośledzonych umysłowo w stopniu głębokim. 